Please do not remove this page

RMIT

UNIVERSITY

\title{
The entanglement of the stuff and practice of human service work: A case for complexity
}

Emslie, Michael

https://researchrepository.rmit.edu.au/esploro/outputs/9921860699801341/filesAndLinks?institution=61RMIT_INST\&index=null

Emslie, M. (2016). The entanglement of the stuff and practice of human service work: A case for complexity. Social Work and Social Sciences Review, 18(2), 25-42.

https://researchrepository.rmit.edu.au/discovery/fulldisplay/alma9921860699801341/61RMIT_INST:Resea rchRepository

Document Version: Published Version 
Thank you for downloading this document from the RMIT Research Repository.

The RMIT Research Repository is an open access database showcasing the research outputs of RMIT University researchers.

RMIT Research Repository: http://researchbank.rmit.edu.au/

\section{Citation:}

Emslie, M 2016, 'The entanglement of the stuff and practice of human service work: A case for complexity', Social Work and Social Sciences Review, vol. 18, no. 2, pp. 25-42.

See this record in the RMIT Research Repository at:

https://researchbank.rmit.edu.au/view/rmit:37703

Version: Published Version

Copyright Statement:

(C) N/A

Link to Published Version:

http://journals.whitingbirch.net/index.php/SWSSR/article/view/896 


\title{
The entanglement of the stuff and practice of human service work: A case for complexity
}

\author{
Michael Emslie ${ }^{1}$
}

\begin{abstract}
The fact that social welfare professions including social work, youth work and community work deal with the lives and relationships of human beings is far from controversial. What is contentious is that in light of increasing intellectual work on the nature of social practices there is a failure in the human services literature to adequately examine the interdependencies and entanglements between conceptualisations of the stuff that the helping professions deals with and understandings of practice. This article examines the nexus and mediations between the phenomena and practice of social service work. The case is made that human services and the human beings they deal with are often imagined and represented in one-dimensional, unambiguous, calculable and orderable ways that align with neo-liberal inspired and technical approaches to practice. I argue that these accounts are inadequate and I suggest that practices of care and the people engaged in such practices should be constituted as complex, unpredictable, wicked and emergent. A key to good practice in the people professions is acknowledging and attending to this complexity and aporia.
\end{abstract}

Keywords: human services; complexity; good practice

1. Lecturer in Youth Work,

Address for correspondence: Michael Emslie, Youth Work, RMIT University, PO Box 2476, Melbourne, VIC 3001, Australia.michael.emslie@rmit.edu.au

Date of first (online) publicaton: 5th May 2016 


\section{Introduction}

Accounts of the nature of practices, or practice ontologies, are flourishing following the 'practice turn in contemporary theory' and growing intellectual interest with neo-Aristotelianism (Dunne, 1993; Greene, 2009; Schatzki, Knorr Cetina and von Savigny, 2001). One way these practice theories can be deployed is to conceptualise good practice in human services (Emslie, 2014; Kemmis and Smith, 2008). Something that different practice ontologies have in common is that practices 'consist of interdependencies between diverse elements' (Shove, Pantzar and Watson, 2012, p. 7). According to Reckwitz (2002, p. 249) these interdependent elements include "forms of bodily activities, forms of mental activities, "things" and their use, a background knowledge in the form of understanding, know-how, states of emotion and motivational knowledge'. Shove et al. (2012, p. 14) similarly argued social practices are made or enacted by people actively combining a number of elements, in particular:

materials - including things, technologies, tangible physical entities, and the stuff of which objects are made; competences - which encompasses skill, know-how and technique; and meanings - in which we include symbolic meanings, ideas and aspirations.

On a similar note Schatzki (2012, pp. 14-15; 2002, pp. 77-80) made the case that practices feature 'open-ended, spatially-temporally dispersed nexus of doings and sayings' that are organised by and are expressions of 'practical rules, [practical] understandings, teleoaffective structures, and general understandings'. And, according to neo-Aristotelian perspectives practices consist of a correspondence between a material that is being dealt with, and a form of knowledge and a type of action best suited to deal with the material in question (Aristotle, 2009; Dunne, 2005; Flyvbjerg, 2001; Polkinghorne, 2004). In this article I examine one element that is critical to human service practices, which are the people who human service practitioners work with. I explore the question how should we conceptualise the stuff that practices of care deal with - the lives and relationships of human beings particularly if we want to achieve good practice in the people professions?

There are good reasons to ask this question. Different accounts of the nature of practices have acknowledged that practices deal with stuff or things. For example this claim is shared by Schatzki (2012) and Dunne (2005) even though other aspects of their conceptualisations of practice differ. According to Schatzki (2012, p. 16);

Just about every practice... deals with material entities (including human bodies) that people manipulate or react to. And most practices would not exists without materialities of the sorts they deal with, just as most material arrangements that practices deal with would not exist in the absence of these practices. 
On a similar note Dunne (2005, p. 378) argued good practice depends upon getting clarity on the subject of,

...just what kind of material we deal with...the material will determine the kind of activity we are engaged in and, in turn, the kind of knowledge that is required or the type of rationality that is appropriate.

When it comes to the caring professions the critical material or phenomena that practices such as social work, youth work, aged care and disability care deal with are people and their lives and relationships. In light of the significance of this stuff to practice of care, if we are serious about conceiving and achieving good practice in human services then we need a good conceptualisation of what it is that such practices are dealing with.

Carlile, Nicolini, Langley and Tsoukas (2013) similarly suggested that the conceptualisations of what it is that practices of social welfare deal with have practical, ethical and ontological implications. According to the authors;

...matter does matter because it generates consequences and, therefore, an ethical dimension grows out of a natural inquiry into the sources of those consequences... matter matters not only as an intellectual effort, but also in an ontological and practical sense, i.e., it generates consequences for how we experience and act in the world. (Carlile et al., 2013, p. 3)

The stuff or things that human services deal with, which I am examining in this article, may not be matter in the sense Carlile et al. (2013) proposed. At the same time the imaginings and representations of human beings and their lives and relationships, which are entities and phenomena that the people professions work with, have ethical, practical and ontological consequences of the kinds that the authors suggest. Freire (1985) and Kemmis (2008) illustrated the point in the field of education. Freire (1985, p. 43) argued, 'Every educational practice implies a concept of man (sic) and the world', and how these things - 'man' and 'the world' are constituted are significant for teaching and learning as well as teachers and learners. Kemmis (2008) demonstrated just that by arguing that praxis in education relies on particular conceptualisations of students.

They are not 'raw material' to be moulded into pre-given shapes and lives, but coparticipants in a shared social life, in which we have shared fates. The educator always encounters them as persons worthy of the recognition and respect due to the Other. (Kemmis, 2008, p. 290)

It is important to acknowledge that there are many material things and different kinds of stuff used in and entangled with human service practices. These include 
technologies such as ICT, instruments including assessment tools, and objects of which cars are a good example. Such matter, and how it is conceived and used, are important elements for practice in the people professions, but these are not the phenomena that are the chief focus of this paper. I concentrate on examining the conceptualisations of one thing that is critical to practices of care, and that is the people and their lives and relationships that such practices work with and for. What's more I am not simply referring to the aspects of people that have been brought into focus recently among practice theorist, namely the physical body, the body as a material entity, or 'nonpropositional bodily abilities' (Schatzki, 2012, pp. 14-16). I begin by examining the human services literature and identify and critique typical ways that the stuff and practice of the caring professions is imagined and represented. I then explore what these characteristic conceptualisations miss and conceal, and I draw on a range of relevant debates in the social sciences to do just that. Finally I make a case for how people and their lives and relationships should be constituted or constructed if we are interested in achieving good practice in social, youth and community work.

\section{Conceptualisations of the stuff and practice of human services in the literature}

In the human services literature there is generally a failure to adequately acknowledge and examine the interdependencies and entanglements between the phenomena that the helping professions deal with and understandings of practice. McDonald (2006) and Neukrug (2012, pp. 69-82) are an exception and the authors provide examples of attempts to make connections between how people or human nature are conceived and approaches to human service practice. For example McDonald (2006, p. 119) argued the case for five 'discourses of welfare' that involved such entanglements.

The first of these is the charitable discourse, in which welfare or service delivery is a gift or donation directed towards a needy supplicant (usually a member of the deserving poor)...The second is the professional discourse... [in which] welfare is a service for the client...The third and more contemporary discourse is that of NPM [New Public Management] in which welfare is a product for the consumer-citizen... The fourth (also contemporary) discourse is that of the market which promotes welfare as a commodity for the customer...The final discursive formation of welfare...is that of community, a contradictory and confusing set of discourses in which welfare promotes participation for the citizen-user... (italics in original) (McDonald 2006, pp. 119-120)

As McDonald demonstrates these accounts fail to make a good case for how we 
should imagine and represent the lives and relationships of human beings if we want to achieve good practice.

Another common problem in the relevant literature is a discrepancy between how people and practice are conceived. For example people and their lives and relationships are often conceptualised as ambiguous, unpredictable, indeterminate and messy. Fook, Ryan and Hawkins (2000) provided such a characterisation of the stuff that human services deal with. However these authors subsequently resorted to a technical conceptualisation of practice to deal with this phenomenon, which does not correspond. In particular they argued good practice involves the application of knowledge in practice, which constitutes the matter being dealt with unambiguous, predictable and a type of stuff that can be made into something other than what it is with the proper use of theory. Fook, Ryan and Hawkins (2000) demonstrated that the matter of human service work is often conceptualised as complex in the literature, but this is not linked to consistent account of practice. More often there is gap in the human services literature. In particular what is missing is an attempt to articulate a well-thought out account of the stuff that the people professions deal with. Instead accounts of practice imply a conceptualisation of human beings and their lives and relationships and what follows are two examples of just that.

\section{Following neo-liberal rationalities of government}

The stuff that human services work with is often conceptualised in one-dimensional ways that correspond to and reproduce neo-liberal rationalities of government. More to the point people are conceived as individual subjects with capacities and responsibilities to exercise freedom, autonomy and choice. And this freedom enables and requires people to pursue, manage and achieve interests in markets along with other autonomous, competitive and self-responsible agents. A key function of practices in the caring professions, when they are organized as an element of this regime of government, is to elicit, promote, facilitate and foster these identities and capabilities (Dean 2010). One way this takes place is with the constitution of people engaged with practices of care as customers or consumers (McDonald, 2006). Dean (2010) argued social welfare has been reconfigured using rationalities and techniques of markets and these reforms contribute to the production of such subjects. A problem with these conceptualisations is that people's different experiences of economic and social advantage and disadvantage, which impacts on the capacity to make choices, is minimised. Another problem is that the responsibility for achieving economic and social well-being is placed onto vulnerable individuals, rather political, economic or social institutions and conditions.

Another basic conceptualisation of people in the human services literature that is entangled with neo-liberal forms of government is as cases or risks to be 
managed (Rose, 1999). In this instance, individual subjects have inadequately demonstrated the exercise of freedom, autonomy and choice. Subsequently they are 'at-risk' and need the 'case-management' support of social services to 'erase risky behaviours' and to nurture and enhance capacities to manage themselves and pursue interests in responsible ways (Dean, 2010, p. 195). Again economic, social and political differences are erased, and individual responsibility for addressing inequality, disadvantage and vulnerability is emphasized. In Australia we have also witnessed the superficial and condemnatory characterisations of people who use social services as 'dole bludgers', welfare dependents, 'leaners', and the undeserving poor (Hockey, 2014). The problem with these conceptualisations is that they are dehumanising, demeaning and demonising of people who demonstrate a need for and are engaged with human services. At the same time such portrayals of people align with neo-liberal rationalities of government. In particular they discourage the reliance on government funded social services. They also justify more intensive interventions and surveillance by governments to promote self-responsibility and the desirable exercise of freedom.

\section{Objects of modern science and technology}

Another way people are imagined and represented in the human services literature is as stuff that can be observed, measured, explained and dominated by intellect and reason. In particular what it is that the caring professions deal with is conceived as something that is 'inevitable, essential, self-evident and universal', and that can be unambiguously, completely and objectively known (Dahlberg and Moss, 2013). These ways of conceptualising people correspond to Heidegger's (1977) account of the essence of modern technology as a mode of revealing, which he called Enframing.

Enframing...demands that nature...reports itself in some way or other that is identifiable through calculation and that it remains orderable as a system of information. (Heidegger 1997, p. 23)

Heidegger (1997) suggested a danger of Enframing is that people conceive themselves and other people as calculable and orderable. Constituted or revealed as being completely knowable, explainable and predictable make human beings amenable to submission, mastery and exploitation by human ingenuity. Put another way, people are thought of in ways that resemble raw material like stone or wood that can be efficiently crafted or engineered with the application of the right sort of rational and scientific aka positivist knowledge. Conceptualisations of people as stuff that can have practice done to and on them are entangled with linear, prescriptive and deterministic approaches to practice that are typically referred to 
as technical, instrumental, standardized, managerial, rule-based, and procedurally orientated. This includes evidence-based practice, outcomes-based practice frameworks, risk-based approaches to practice, transferable skills handbooks, and instruction manuals (Hamilton, 2005; Schon, 1987, 1991). Other examples include practice based on psychological and neuroscientific theories of human beings (Bessant and Watts, 2012; Milevsky, 2014)

Such approaches to conceiving people and practice are common and actively embraced and pursued by governments and human service providers because of their promise to improve cost-efficiency and enhance service effectiveness. The social sciences and affiliated researchers and practitioners also have a long history of imagining and representing the human as 'objects of science' as a way to gain intellectual legitimacy on par with the natural sciences (Olsen, 2013, p. 175). Moreover there have been desperate and enduring attempts in much social research and theory to transfer and apply the methods of the positivist natural sciences, used to conceptualise and explain a solid, certain, immutable, predictable, and rulefollowing account of matter, onto things and entities such as culture, the social, morality, and people and their lives and relationships (Dunne, 2005; Flyvbjerg, 2001; Polkinghorne, 2004). If the conceptualisations of people and practice inspired by neo-liberal rationalities of government and modern science and technology are inadequate then how should they be imagined and represented?

\section{Exploring other ways of conceiving what it is that human services deal with}

Conceptualisations of the stuff and practice of human service work that are inspired by and entangled with neo-liberal rationalities of government and technical approaches to practice miss and, according to Heidegger (1977), conceal ways of imagining and representing people and their lives and relationships. A range of relevant debates within the social sciences demonstrate just that and these controversies suggest that what it is that the people professions deals with is different and more than being one-dimensional, unambiguous, calculable and orderable.

\section{A fixed structure of meaning or an effect of power/knowledge}

Contemporary cultural studies have undermined the idea that people are born into the world already formed with, for example, an innate and natural potential for good or bad. According to Mansfield (2000, p. 11) there is a consensus amongst theorists since Heidegger that the subject is constructed rather than an authentic, 
autonomous and naturally occurring thinking, feeling and acting thing. Mansfield (2000) argued there are two broad approaches to theorising the self that have dominated the second half of the twentieth century. The subjectivist camp is illustrated by Freud, Lacan, and most accounts of psychiatry and psychology. It also includes structural accounts of Marxism and feminism, and much subcultural theory. This approach;

... attempts to explain the truth of the subject... Its authority rests on the assumption... that its object of analysis is quantifiable and knowable - in short a real thing, with a fixed structure, operating in knowable and predictable patterns... For these theorists, the subject has a knowable content, and is measurable against a normative path of development. (Mansfield, 2000, pp. 9, 66)

Human service practice that follows and is based on this account of the self focuses on supporting, organising and correcting individuals to be normal and self-sustaining, including preventing and healing abnormal behaviour. Such practice also reproduces the belief that people have an essence and a true, authentic, complete, essential and inevitable self that needs to be helped, protected, liberated, and empowered in the face of power, oppression, adversity and alienation.

Alternatively, according to anti-subjectivist approaches 'the subject is an effect of power, science or technologies' (Mansfield, 2000, p. vi). In other words there is no true self to be liberated and any account, thought, feeling, or idea of the self is a construction emanating from power/knowledge, such as that exercised by human service professionals. Proponents of this position include Nietzsche, Foucault, and Deleuze and Guattari.

[This] approach to the subject...believes neither that the subject has a fixed or knowable content, nor in fact that subjectivity exists outside of the demands power places on individual bodies to perform in certain ways. Power, in its drive to administer human populations, contrives the subject as an ideal mode of being to which we must conform...We are the very material of power, the thing through which it finds its expression. (Mansfield, 2000, p. 66, 55)

To put this another way, the idea of subjectivity, 'has been invented by dominant systems of social organisation in order to control and manage us' (Mansfield, 2000, p. 10).

...'subjectivity'... is the way we are led to think about ourselves, so we will police and present ourselves in the correct way, as not insane, criminal, undisciplined, unkempt, perverse or unpredictable. (Mansfield, 2000, p. 10)

According to the anti-subjectivist camp any practice of social welfare, which 
is entangled with a conceptualisation of the human, is a technique of power and social administration making demands of and disciplining us. The anti-subjectivist position raises insurmountable hurdles for knowing and realising good practice in human services. Any conceptualisation of caring work produces and reproduces the subject in limited and limiting ways, and caring professionals should be interested in examining the conceptualisations they are producing and reproducing, as well as the forms of power/knowledge, interests and ideologies these meanings serve. The subjectivist anti-subjectivist debate suggests that those who work in the people professions should not delude themselves that they are doing good practice.

\section{The natural science and social science distinction}

According to the subjectivist approach to theorising the self, people and their lives and relationships have a truth that can be observed, measured, explained and predicted. The anti-subjectivist position is one critique of this account. Another criticism can be found in debates between the natural, physical or theoretical sciences and social, human or practical sciences (Blaikie, 2007, pp. 30-55; Egan, 2010, p. 16-17; Giddens, 1993; Thompson, 2000, pp. 43-53). As previously argued many approaches to human service practice conceptualise human beings in ways that matter is typically conceptualised in the natural sciences as completely knowable and subsequently explainable, calculable, predictable, and tameable. Conceived in this way people can be known in decontextualized, universal, valuefree and rule-based ways that are entangled with forms of practice based on such knowledge.

However there are many arguments and proponents for conceptualising the stuff of human service work as a different to this account (Flyvbjerg, Landman and Schram, 2012; Hamilton, 2005). For example, in the eighteenth century Vico (1999, p. 114) argued, 'Sciences must begin at the point where their subject matter begins', and he argued for a distinction between natural sciences that dealt with the physical universe, and poetic sciences that focus on the human world. Vico conceptualised the substances or stuff of the physical domain and the human realm as distinct and deserving of different ways of knowing. Similarly Einstein argued,

...one of the strongest motives that lead men to art and science is escape from everyday life with its painful crudity and hopeless dreariness, from the fetters of one's own ever-shifting desires. A finely tempered nature longs to escape from the personal life into the world of objective perception and thought. (Schweber, 2008, p. 6)

Flyvbjerg (2001, p. 32) agreed arguing there are critical differences between the material that the natural and social sciences deals with; 
...the former [natural sciences] studies physical objects while the latter [social sciences] studies self-reflecting humans and must therefore take account of changes in the interpretations of the objects of study. Stated in another way, in social sciences, the object is a subject.

Put simply Chenoweth and McAuliffe (2012, p. 205) argued;

One of the main distinguishing features of human service organisations is the nature of the work undertaken - that is, human service work with people rather than with objects.

If the things and entities that the people professions deal with are better known for their introspective, not always apparent, fluid, ephemeral, self-reflecting, reflexive, and emergent meaning making qualities then they are not amenable to the sorts of practices that are interdependent with the knowledge traditionally produced by the approaches and methods of the hard sciences. Moreover the conceptualisations of the stuff of human service work as objects of the natural positivist sciences or subjects of an interpretive, critical and phronetic social science have irreconcilable epistemological, ethical and practice entanglements and implications. Recent accounts of complexity theory, aspects of practice theory, and the conceptualisation of the human as cyborg counter and complicate the object/subject split (Blaikie, 2007, pp. 206-214; Carlile et al., 2013; Haraway, 1991; Introna, 2013; Latour, 2002; Schatzki, 2012, pp. 13-24). However these theories typically provide further rebuttal to the conventional natural science conceptualisation of matter.

\section{Knowable versus aporia}

One of the differences between the positivist and interpretivist conceptualisations of human beings is that they are or are not completely knowable. This debate warrants further attention. Since Descartes (2009) famously argued 'I think therefore I am' people have been conceived as individuals with conscious minds that have the capacities of intellect and reason that can be put to use to search for, know and explain a complete, coherent and consistent truth of the world. This definition of the self was a bedrock of the Enlightenment and Rationalism, and remains influential. According to Barad (2013, p. 20) humans have an 'ultimate wish for complete knowability' and conceptualise matter as entirely knowable. Moreover Descartes' Cogito was the precursor to the conceptualisation of the stuff that human services deal with as absolutely unambiguously intelligible. This frames the problem of knowing and achieving good practice as a problem solving exercise that is amenable to right or wrong, correct or false answers. And though this puzzle may be complicated, according to this conceptualisation the various elements to achieve 
good practice, including the stuff that practice deals with, can be broken down and linear and predictable relationships between variables established on the basis of calculable and calculated probabilities, correlations and causations.

However as Mansfield (2000, p. 20) observed this account of the self relies on suppressing and obscuring other dimension of subjectivity, including the unconscious, inconsistent, irrational, obscure and unknown. Heidegger and Bourdieu are examples of philosophers who argued that people may not be immediately aware of why they do what they do, and rational explanations of human action can be inadequate. According to Hume passions precede and shape reason. And Burke, Midgley and Roberto Unger argued humans have ethical and emotional capacities and the intellectual and rational dimensions of self should not be privileged. In other words conceiving people and their lives and relationships as completely knowable has sustained significant critique and does not stand up to scrutiny. More to the point we cannot easily articulate and know everything about people and their lives and relationships. Other examples of elements of human beings and human service practice that are arational include tacit knowledge, intuitions, instincts, gut feelings, passions, emotions, counter-transference, unconscious bias, spontaneity, chance, luck or tuche, good timing or kairos, and a 'good eye' (Benner, 1984; Collins, 1990; Dreyfus and Dreyfus, 1986; Ericsson, 2006; Pannabecker, 1994; Polanyi, 1996, 1962; Schon 1991). Other tendencies of humans that get in the way of our rational capacities include scotoma, or not seeing bad practice, wickedness and 'shadows', inertia, and ignorances (Cohen, 2001; Gambrill, 2013, p. ix; Jung, 1973; Midgley, 1984; Nussbaum 2013). It should as no surprise in light of these characterisations of people and practice that Green $(2009$, p. 11) argued professional practice is characterised by aporia, or the confrontation with unresolvable problematics, paradoxes, perplexities and impossibilities.

In professional practice there are always moments of undecidability and decision, moments when one must act, even if the way forward is not clear, or - more radically - is uncertain. (Green, 2009, pp. 11-12)

Imagining and representing people and practice as not completely knowable, enigmatic, and unable to be known by reason alone suggests that figuring out and doing good caring work is not amenable to right or wrong, correct or false answers. Instead such a conceptualisation suggests the problem and the solution are forever uncertain and always incomplete, and 'are part of the same emerging complex system which is never fully "present" in any (discrete) moment in time' (Osberg, Biesta and Cillers, 2008, p. 213) 


\section{Simple or complex}

A further series of debates echo the controversies just mentioned. The differences between conceptualisations of tame and wicked problems and solutions is one example (Australian Public Service Commission, 2007 ; Rittel and Webber, 1973). Deleuze and Guattari's (1987) contrast between the stable and unified arborescent system and the dynamic multidimensional rhizome is another. These distinctions resonates with the dissimilarities between characterisations of simple, obvious, linear and complicated phenomena, and complex, emergent, non-linear and chaotic phenomena (Blaikie, 2007, pp. 206-214). For example Davis and Sumara (2006, p. 11) argued;

....although a complicated system might have many components, the relationship among those parts is fixed and clearly defined. If it were carefully dismantled and reassembled, the system would work in exactly the same way. However, there exist some forms that cannot be dismantled and reassembled, whose characters are destroyed when the relationships among components are broken. Within these sorts of complex systems, interactions of components are not fixed and clearly defined, but are subject to ongoing co-adaptations.

Similarly Snowden and Boone (2007, nd) argued;

Simple and complicated contexts assume an ordered universe, where cause-andeffect relationships are perceptible, and right answers can be determined based on the facts. Complex and chaotic contexts are unordered-there is no immediately apparent relationship between cause and effect, and the way forward is determined based on emerging patterns.

In the same way Schon (1987, p. 3) made the case for a distinction between straightforward and difficult problems;

In the varied topography of professional practice, there is a high, hard ground overlooking a swamp. On the high ground, manageable problems lend themselves to solution through the application of research-based theory and technique. In the swampy lowland, messy, confusing problems defy technical solution...in the swamp lie the problems of greatest human concern

Barad (2013, p. 18) echoed Schon by contrasting 'bedrock of solid and certain knowledge' to 'the swamp of ignorance and uncertainty'. Conceiving the stuff that human services deal with as like hard bedrock or a swampy mess are interdependent with conceptualisations of good practice as complicated but technically possible compared to complex and always uncertain. 


\section{Complex people, complex practice}

These debates suggest that the usual ways that the stuff and practice of the people professions are imagined and represented are inadequate. In particular human services and the human beings they deal with are more than the one-dimensional, unambiguous, calculable and orderable conceptualisations that typically feature in the relevant literature. The controversies also suggest that the phenomena and practice of social, youth and community work are better conceived as complex, unpredictable, wicked and emergent. A key to good practice in the people professions is acknowledging and attending to this complexity and aporia and a number of approaches to practice suggest ways of doing just that. In particular if conceptualisations of people and practice are effects of power/knowledge then the way subjects and practices are constituted warrants constant reflexive attention and value rational deliberation (Bourdieu and Wacquant, 1992; Flyvbjerg, 2001). And if conceptualisations of people and practice are interpretive, interest-laden and value-based judgments rather than scientific facts then neo-Aristotelian inspired approaches to human service practice that promote the role of practical wisdom or phronesis may have something valuable to offer (Bondi, Carr, Clark and Clegg, 2011; Schwartz and Sharpe, 2010). And if conceptualisations of people and practice are wicked and emergent then ongoing attention to detail and context, and continuous interpretation and deliberation about problem setting and problem framing is worthwhile (Rittel and Webber, 1973; Schon, 1991)

Greene (2001), to some degree following Heidegger's (1977, p. 25) account of 'the mystery', also makes a salient point. She argued that in the domain of art there is 'the wonder, the challenge, the surprises...And, yes, the mystery, that goes beyond explanation' (Greene 2001, p. 141). Similarly, when it comes to imagining and representing people and human service practice; 'There is always, always more' (Greene, 2001, p. 14). And any conceptualisation of people and practice is limited and limiting. People are always more than any construction that forecloses possibility such as equations to be solved, objects to be produced, machines to be optimized, matter to be mastered and controlled, or investments to render future benefit. People are always more than any label, and they are always more than any conceptualisation such as being programmable like computers or stuff that can be manipulated, fashioned, controlled, exploited, mechanized, designed or engineered into things. Similarly good human service practice is always more than the reductionist and limited ways of thinking about and doing caring work inspired by neo-liberal forms of government, technical rationality, and positivist natural sciences that suggest everything can be unambiguously and completely known, ordered, controlled, planned, predicted, and streamlined. 


\section{Conclusion}

According to recent accounts of practice theory the way people and their lives and relationships are conceived is entangled and interdependent with how practices of care are constructed and enacted. This logic suggests that a critical element for achieving good practice in youth and community work is a good conceptualisation what it is that such practices deal with. I argued that in the human services' literature representations of the stuff that people professions deal with are often flawed. The lives and relationships of human beings are often constituted in one dimensional ways that follow and reproduce neo-liberal rationalities of government. And they are constructed as phenomena that can be unambiguously and completely known and that is amenable to technical approaches to practice. And there are discrepancies and inadequacies with how people and practice are conceived.

I explored a range of debates on the nature of what it is that the people professions work with. These controversies suggested that there is no certain, solid, ordered, objective, absolute, factual, perfect, eternal, universal, unchanging account of people. Instead human beings and their lives and relationships are better imagined and represented as wicked, complex, emergent, non-linear, difficult, forever uncertain, and always incomplete. Furthermore any construction is an interpretation that is prejudiced, interestladen and value-based. In light of these disagreements and possibilities I argued that the nature of the things and practice of human service work should be conceptualised as complex, unpredictable, wicked and emergent. I suggested a key to good practice in the people professions is acknowledging and attending to this complexity and aporia, and I provided examples of approaches to practice that aim to do just that. There is a need for further research how those who are interested in achieving good practice in caring work can and should work with phenomenon that is forever uncertain and always incomplete.

\section{References}

Aristotle (2009) The Nicomachean ethics. (rev. ed.) trans. D. Ross. Oxford: Oxford University Press

Australian Public Service Commission (2007) Tackling wicked problems: A public policy perspective. Canberra: Commonwealth of Australia

Barad, K. (2013) Ma(r)king time: Material entanglements and re-memberings: Cutting together-apart. in Carlile, P., Nicolini, D., Langley, A. \& Tsoukas, H. (Eds.) How matter matters: Objects, artefacts, and materiality in organisational studies. Oxford: Oxford University Press (pp.16-31) 
Benner, P. E. (1984) From novice to expert: Excellence and power in clinical nursing practice. Menlo Park, CA: Addison-Wesley

Bessant, J. and Watts, R. (2012) The mismeasurement of youth: Why adolescent brain science is bad science. Contemporary Social Science: Journal of the Academy of Social Sciences. 7, 2, 181-196

Blaikie, N. (2007) Approaches to social enquiry. (2 ${ }^{\text {nd }}$ ed.) Polity Press: Cambridge, UK

Bondi, L., Carr, D., Clark, C. \& Clegg, C. (Eds.) (2011). Towards professional wisdom: Practical deliberation in the people professions. Aldershot: Ashgate

Bourdieu, P. \& Wacquant, L. (1992) An invitation to reflexive sociology. Chicago: University of Chicago Press

Carlile, P., Nicolini, D., Langley, A. \& Tsoukas, H. (eds.) (2013) How matter matters: Objects, artefacts, and materiality in organisational studies.Oxford: Oxford University Press

Chenoweth, L. and McAuliffe, D. (2012) The road to social work and human service practice.( $3^{\text {rd }}$ ed.) South Melbourne: Cengage Learning Australia

Cohen, S. (2001) States of denial: Knowing about atrocities and suffering. Cambridge: Polity

Collins, H. (1990) Artificial experts: Social knowledge and intelligent machines. Cambridge, MA : MIT Press

Dahlberg, G. and Moss, P. (2013) Series editors' introduction. in, Sellers, M. Young children becoming curriculum: Deleuze, Te Whariki and curricular understandings. Abingdon, Oxon : Routledge (pp,x-xiii)

Davis, B. \& Sumara, D. (2006) Complexity and education: Inquiries in learning, teaching, and research. Mawah: NJ : Lawrence Erlbaum

Dean, M. (2010) Governmentality: Power and rule in modern society, (2 ${ }^{\text {nd }}$ ed.) London : Sage

Deleuze, G. \& Guattari, F. (1987) Capitalism and schizophrenia. Volume 2: A thousand plateaus. trans. B. Massumi. Minneapolis: University of Minnesota Press

Descartes, R. (2009) Discourse on method. trans. J. Veitch. New York : Everyman E. P. Dutton:

Dreyfus, H. \& Dreyfus, S. (1986) Mind over machine: The power of human intuition and expertise in the era of the computer. Oxford: Basil Blackwell

Dunne, J. (2005) An intricate fabric: understanding the rationality of practice. Pedagogy, Culture and Society, 13, 3, 367-389

Dunne, J. (1993) Back to the rough ground: Practical judgment and the lure of technique. Notre Dame, IN : University of Notre Dame

Egan, G. (2010) The skilled helper: A problem-management and opportunity-development approach to helping. ( $9^{\text {th }}$ ed.) Belmont, CA: Brooks/Cole, Cengage Learning

Emslie, M. (2014) Conceiving good practice in the caring professions. Developing Practice: The Child, Youth and Family Work journal, 38, April, 65-74 
Ericsson, K. A. (2006) An introduction to The Cambridge handbook of expertise and expert performance: Its development, organization, and content. in, Ericsson, K. A., Cherness, N., Feltovich, P. \& Hoffman, R. (Eds.) The Cambridge handbook of expertise and expert performance. Cambridge: Cambridge University Press (pp. 3-19)

Flyvbjerg, B. (2001) Making social science matter. Cambridge: Cambridge University Press

Flyvbjerg, B., Landman, T. \& Schram, S. (Eds.) (2012) Real social science: Applied phronesis. Cambridge: Cambridge University Press

Fook, J., Ryan, M. \& Hawkins, L. (2000) Professional expertise: Practice, theory and education for working in uncertainty. London: Whiting \& Birch

Freire, P. (1985) The politics of education: Culture, power and liberation. trans. D. Macedo. Westport, CT : Bergin and Garvey

Gambrill, E. (2013) Social work practice: A critical thinker's guide. ( $3^{\text {rd }}$ ed.) New York : Oxford University Press

Giddens, A. (1993) New rules of sociological method. (2 ${ }^{\text {nd }}$ ed.) Cambridge, MA: Polity

Green, B. (ed.) (2009) Understanding and researching professional practice. Rotterdam: Sense Publishers

Greene, M. (2001) Variations on a blue guitar: The Lincoln Center Institute lectures on aesthetic education. New York: Teachers College Press, Columbia University

Hamilton, D. (2005) Knowing practice. Pedagogy, Culture and Society, 13, 3, 285-289

Haraway, D. (1991) Simians, cyborgs, and women: The reinvention of nature. London: Routledge

Heidegger, M. (1977) The question concerning technology and other essays. trans. W. Lovitt. New York : HarperCollins

Hockey, J. (2014) Joe Hockey: We are a nation of lifters, not leaners. Financial Review, May 14, (2014, accessed September 15 2015, http://www.afr.com/news/policy/tax/ joe-hockey-we-are-a-nation-of-lifters-not-leaners-20140513-ituma

Introna, L. (2013) Otherness and the letting-be of becoming: Or, ethics beyond bifurcation. in, Carlile, P., Nicolini, D., Langley, A. \& Tsoukas, H. (Eds.) How matter matters: Objects, artefacts, and materiality in organisational studies. Oxford: Oxford University Press (pp. 260-287)

Jung, C. (1973) Aion: Researches into the phenomenology of the self. Princeton: NJ: Princeton University Press

Kemmis, S. (2008) Epilogue: A radical proposal. in Kemmis, S. and Smith, T. (Eds.) Enabling praxis: Challenges for education. Rotterdam: Sense Publishers (pp.287-295)

Kemmis, S. and Smith, T. (Eds.) (2008) Enabling praxis: Challenges for education. Rotterdam: Sense Publishers

Latour, B. (2002) Morality and technology: The end of the means. trans. C. Venn. Theory, Culture and Society. 19, 5/6, 247-260

Mansfield, N. (2000) Subjectivity: Theories of the self from Freud to Haraway. New York: New York University Press 
McDonald, C. (2006) Challenging social work: The institutional context of practice. New York: Palgrave MacMillan

Midgley, M. (2002) Wickedness. London: Routledge,

Milevsky, A. (2014) Understanding adolescents for helping professionals. New York : Springer

Neukrug, E. (2012) Theory, practice, and trends in human services: An introduction. (5 ${ }^{\text {th }}$ ed.) Belmont, CA: Brooks/Cole, Cengage Learning

Nussbaum, M. (2013) Political emotions: Why love matters for justice. Chicago: University of Chicago Press

Olsen, B. (2013) Reclaiming things: An archaeology of matter. in, Carlile, P., Nicolini, D., Langley, A. \& Tsoukas, H. (Eds.) How matter matters: Objects, artefacts, and materiality in organisational studies. Oxford: Oxford University Press (pp.171-196)

Osberg, D., Biesta, G. \& Cilliers, P. (2008) From representation to emergence: Complexity's challenge to the epistemology of schooling. Educational Philosophy and Theory, 40: 213-27

Pannabecker, J. R. (1994) Diderot, the mechanical arts and the encyclopedie: In search of the heritage of technical education. Journal of Technology Education, 6, 45-57

Polanyi, M. (1966) The tacit dimension. Gloucester, MA: Peter Smith

Polanyi, M. (1962) Personal knowledge: Toward a post-critical philosophy. [Corrected Edition]. Chicago: The University of Chicago Press:

Polkinghorne, D. (2004) Practice and the human sciences: The case for a judgment-based practice of care. Albany: State University of New York Press

Reckwitz, A. (2002) The status of the 'material' in theories of culture: From 'social structure' to 'artefacts'. Journal for the Theory of Social Behaviour. 32, 2, 195-217

Rittel, H. \& Webber, M. (1973) Dilemmas in a general theory of planning. Policy Sciences. 4, 155-169

Rose, N. (1999) Powers of freedom: Reframing political thought. Cambridge: Cambridge University Press

Schatzki, T. (2012) A primer on practices. in Higgs, J. , Barnett, R., Billett, S. \& Hutchings, M. (Eds.) Practice-based education: Perspectives and strategies. Rotterdam: Sense Publishers (pp13-26)

Schatzki, T., Knorr Cetina, K. \& von Savigny, E. (eds.) (2001) The practice turn in contemporary theory. London: Routledge

Schon, D. (1991) The reflective practitioner: How professionals think in action. Aldershot: Ashgate

Schon, D. (1987) Educating the reflective practitioner: Toward a new design for teaching and learning in the professions. San Francisco: John Wiley

Schwartz, B. \& Sharpe, K. (2010) Practical wisdom: The right way to do the right thing. New York: Riverheads

Schweber, S. (2008) Einstein and Oppenheimer: The meaning of genius. Cambridge: MA: Harvard University Press 
Shove, E., Pantzar, M. \& Watson, M. (2012) The dynamics of social practices: Everyday life and how it changes. London: Sage

Snowden, D. and Boone, M. (2007) A leader's framework for decision making. Harvard Business Review. Accessed 12 September 2015, https://hbr.org/2007/11/a-leadersframework-for-decision-making

Thompson, N. (2000) Theory and practice in human services. Buckingham: Open University Press

Vico, G. (1999) New science: Principles of the new science concerning the common nature of nations, ( $3^{\text {rd }}$ ed.). trans. D. Marsh. Harmondsworth: Penguin 